\title{
Bibliotecas de faculdades de arquitetura sob o foco da ergonomia
}

\section{Architecture college libraries under ergonomic focus}

VILMA VILAROUCO
Doutora em Engenharia, PPGDesign e PPErgo-UFPE; PPGAU+D-UFC, vvillarouco@gmail.com

THANARA PEREIRA E SILVA

Graduanda de Arquitetura e Urbanismo, UFC, thanarapereira.silva@arquitetura.ufc.br

MARIA RAQUEL MARTINS MEDEIROS

Graduanda de Arquitetura e Urbanismo, UFC, raquelmedeiros@arquitetura.ufc.br

ANA MARÍLIA DE ARAÚJO OLIVEIRA

Graduanda de Arquitetura e Urbanismo, UFC, anamarilia@arquitetura.ufc.br

HELAINE LIMA CAMARA

Graduanda de Arquitetura e Urbanismo, UFC, helaine.hel@gmail.com

\section{RESUMO}

Este artigo apresenta uma avaliação ergonômica realizada em bibliotecas de faculdades de arquitetura em universidades públicas do nordeste, visando estabelecer comparação entre os resultados e identificar a adequação desses ambientes. Utilizando a MEAC como metodologia de avaliação, o trabalho conclui que há diversos problemas nos dois casos analisados, sendo estes muito similares. PALAVRAS-CHAVE: bibliotecas, faculdades de arquitetura, avaliação ergonômica de ambientes, MEAC.

\section{ABSTRACT}

This work presents an ergonomic's evaluation made at architectural college libraries located at public universities of northeast, aiming to establish a comparative between all the results and to identify an improvement for this places. Using MEAC as an evaluative methodology, this work concludes that there are many problems in both cases that were analyzed, and also a big similarity with them.

KEYWORDS: libraries, architectural colleges, environmental ergonomic evaluations, MEAC. 


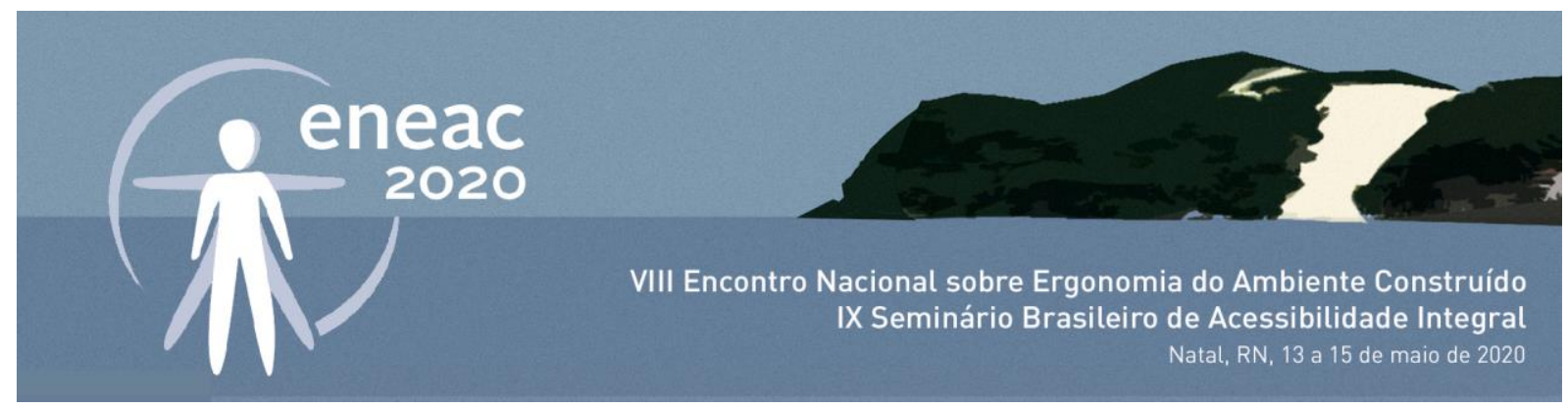

\section{INTRODUÇÃO}

As bibliotecas representam espaços de extrema importância em universidades. Desempenhando funções múltiplas, acolhem os estudantes para a busca e consulta de material bibliográfico, o estudo individual e o estudo em pequenos grupos, devendo ser o lugar que proporciona condições de conforto e adequação ao desempenho das atividades.

Russo (1998, p.4) afirma que as bibliotecas universitárias "são consideradas como segmentos de vital importância na estrutura da instituição, visto o seu caráter de promover o acesso e a disseminação da informação para que os objetivos da universidade sejam plenamente atingidos."

Segundo Prado (2003 apud SOARES, VASCONCELOS e VILLAROUCO, 2009a), a biblioteca deve atender aos seus usuários e ter como diretriz o acervo necessário e adequado aos cursos oferecidos pela instituição da qual faz parte. 0 ambiente, segundo a autora, deve ser agradável aos usuários, harmonicamente organizado e bem planejado, com cores e mobiliário que inspirem um ar positivo, já que se caracteriza como um espaço onde as pessoas costumam passar algumas horas.

\footnotetext{
"Desta forma, pode-se dizer que uma biblioteca existe principalmente para tornar possível o uso, por um dado público, de suas coleções de documentos; que os conhecimentos contidos nos documentos e mantidos nas bibliotecas devem ser transferidos; e que a função social da biblioteca, enquanto instituição social, está principalmente em ser a interface, ou a mediadora entre indivíduos e o conhecimento de que eles necessitam." (SOARES, VASCONCELOS e VILLAROUCO, 2009a)
}

Portanto, pode-se inferir que o espaço da biblioteca precisa abrigar os materiais necessários para o público que a utiliza e que seja mantido de forma adequada, além de possuir diretrizes com relação aos espaços existentes, embasadas nas atividades que se espera realizar dentro do espaço, tanto relativas à busca, retirada e devolução de materiais, espaços de estudo em grupo e individual e locais de estar. Aspectos relativos ao condicionamento ambiental também são importantes em virtude das atividades realizadas no local, como iluminação, conforto térmico e níveis de ruído. É imprescindível que espaços como as bibliotecas sejam adequadas e convidativas para os indivíduos, para que ela possa cumprir com sua função.

Nesse sentido, condições adequadas de conforto são importantes, visto que a qualidade dos fatores térmicos, acústicos e luminosos, de dimensionamento e layout, da segurança, dos materiais de revestimento e demais características ambientais, podem influenciar nas atividades de concentração, leitura e aprendizagem.

Concorda-se então com Vasconcelos et al (2009b), quando pontuam que as sensações provocadas pelo ambiente são interpretadas pelos usuários de acordo com suas preferências e valores, dependendo de sua história e contexto sociocultural, e para a análise das ambiências físicas não se deve apenas considerar as medições físicas e o uso de normas, mas também em compreender as necessidades do indivíduo a fim de lhe proporcionar um espaço agradável de prazer e bem-estar. 0 não atendimento a estes fatores pode ocasionar desconfortos, incômodos, efeitos diretos sobre o desempenho e a produtividade, como também possíveis prejuízos à saúde e falta de segurança.

Focando estes conceitos, a Ergonomia do Ambiente Construído (EAC), como disciplina científica, caracteriza-se pelo estudo do relacionamento existente entre o homem e sua atividade laboral, analisando suas interações ocorrentes no universo que ocupa, preocupando-se com a forma como as 


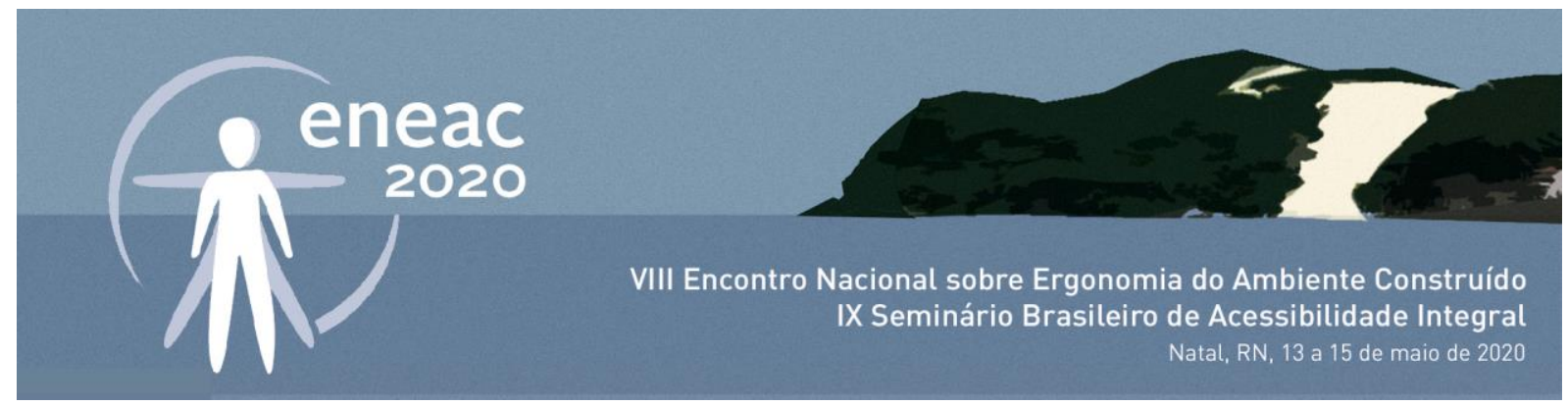

pessoas interagem com o ambiente a partir dos aspectos sociais, psicológicos, culturais e organizacionais.

Mont'Alvão (2011), ressalta que integrando a ideia de ambiente arquitetônico com o ambiente do desenvolvimento das tarefas, de acordo com as capacidades, habilidades e limitações humanas - o que inclui características como percepção, compreensão e interação com o espaço - parece clara a necessidade dos conhecimentos da Ergonomia nos projetos de Design e a Arquitetura que contemplam o ambiente construído.

Agrega-se ainda a colocação de Butti, apud Reis (2003):

\begin{abstract}
"a ergonomia do ambiente construído deve se ocupar de quem usará, que coisa será usada, mas principalmente onde virá a ser usada. Onde é o ambiente de destinação que deve ser analisado como lugar físico e sociocultural que condiciona a interação entre o homem e o objeto".
\end{abstract}

Este é o contexto no qual o presente trabalho foi desenvolvido. Inserido no âmbito da ergonomia do ambiente construído, trás à tona a temática das bibliotecas universitárias, particularizando em bibliotecas inseridas em edificações que abrigam cursos de arquitetura e urbanismo, estando uma delas na Universidade Federal do Ceará e a outra na Universidade Federal de Pernambuco, constituindo-se em um estudo de caso duplo.

\title{
2. METODOLOGIA DO TRABALHO
}

O estudo aqui apresentado parte de algumas questões que nortearam a pesquisa: as bibliotecas de faculdades de arquitetura são adequadas ao desenvolvimento das atividades nelas abrigadas? quanto à percepção dos usuários, elas atendem às expectativas? conforme as normas técnicas, estão em conformidade?

Para responder às indagações, duas bibliotecas inseridas em faculdades de arquitetura de universidades federais nordestinas foram avaliadas, uma nos anos de 2010 e 2012 (a segunda avaliação após algumas intervenções), e a outra, no ano de 2019 , esclarecendo-se que não houve mudanças significativas na primeira nesta quase uma década de lacuna temporal.

É uma pesquisa aplicada e aborda o problema de forma qualitativa adotando o estudo de dois casos, logo, trabalha com amostra intencional selecionada a partir do interesse da pesquisa. De acordo com Gil (2008), este tipo de estudo de caso pode ser classificado como coletivo, que é aquele cujo propósito é o de estudar características de uma população. Esse tipo de estudo é selecionado porque se acredita que, por meio deles, torna-se possível aprimorar o conhecimento acerca do universo a que pertencem. Sob o ponto de vista dos objetivos é um estudo exploratório, pois proporciona maior familiaridade com o problema visando sua explicitação (Gil, 2010).

A pesquisa teve por objetivo avaliar ergonomicamente as bibliotecas, através da Metodologia Ergonômica para o Ambiente Construído - MEAC de Villarouco (2007), gerando uma análise comparativa dos resultados encontrados. A autora coloca que a MEAC atende ao que é primordial na Ergonomia: a adaptação das situações de trabalho ao usuário, ao considerar, também, o sentimento que este vivencia na interação cotidiana com o ambiente construído. Ela é composta de seis fases subdivididas em dois blocos. No primeiro bloco ocorre a análise física do ambiente, que se desmembra em três etapas: análise global do ambiente, identificação da configuração ambiental e 


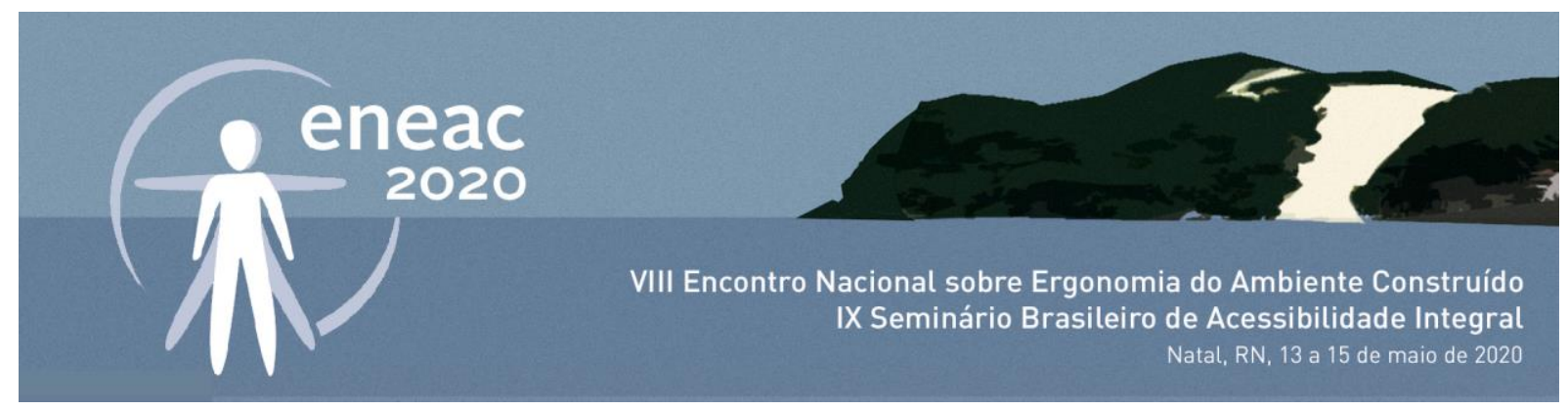

avaliação do ambiente em uso. Já o segundo bloco, trata da percepção ambiental pelo usuário. A avaliação termina com o diagnóstico ergonômico do ambiente e as recomendações e proposições ergonômicas. A MEAC busca não só analisar e propor mudanças no ambiente físico com base em normas e avaliação do pesquisador, mas também foca na percepção do usuário em relação ao espaço.

\section{RESULTADOS DA AVALIAÇÃO PELA MEAC}

\subsection{Biblioteca do CAC - UFPE}

Os dados de avaliação desta biblioteca foram extraídos de Ferrer (2012), conjugados aos trabalhos citados, decorrentes deste projeto de pesquisa.

\subsubsection{Análise Global do Ambiente}

A biblioteca está localizada no hall principal, bem próxima ao acesso, no edifício do Centro de Artes e Comunicação (CAC), onde encontra-se o curso e departamento de arquitetura e urbanismo, além de outros sete departamentos que são letras, design, expressão gráfica, ciência da informação, comunicação social, teoria da arte e expressão artística e música. Ao adentrá-la, os usuários são convidados a deixar seus volumes guardados nos armários, visto que é proibido o acesso à área do acervo com os mesmos. $\mathrm{O}$ espaço dispõe de mesas coletivas para estudos e consulta aos livros e periódicos, como também cabines para estudos individuais. As atividades de empréstimo e devolução dos volumes são realizadas por um funcionário da biblioteca no balcão de atendimento. Todo o ambiente tem uma aparência escurecida, de pouca luminosidade.

Grosso (2018) coloca que neste prédio está presente o conceito da Arquitetura Moderna que se convencionou chamar de Brutalismo. Este termo é empregado para designar as obras de uma das tendências mais características da Arquitetura Moderna, presentes no panorama arquitetônico brasileiro e internacional, que abrange o período pós segunda Guerra Mundial, da década 20 até pelo menos meados da década de 1970, sendo difundidas em todo o mundo.

O edifício do CAC teve seu projeto concluído no ano de 1973, sendo inaugurado no ano de 1976, no fim do movimento brutalista do modernismo. Assim, a estética do edifício do CAC é notadamente marcada pelo uso do concreto aparente e com exposição dos materiais de vedação. Com tais características, a edificação apresenta pilares e tetos em concreto sem revestimentos, paredes em blocos cimentícios na sua cor natural cinza e piso em granito de alta resistência preto fundido no local, sendo todos estes, elementos que escurecem o fortemente ambiente.

Inserida no projeto original da edificação, a biblioteca foi concebida para este fim, recebendo duas reformas de ampliação ao longo do tempo, que mantiveram todas as características originais, de estrutura, modulação, elementos de vedação, revestimento de piso e a predominância da cor cinza.

\subsubsection{Identificação da Configuração Ambiental}

Nesta etapa são identificados todos os condicionantes físico-ambientais, devendo-se manter bastante claro os principais focos da ergonomia: o usuário e o desempenho do ambiente quando do seu uso. Realiza-se o levantamento de todos os dados do ambiente, tais como dimensionamento, iluminação, ventilação, ruído, temperatura, layout, deslocamentos, materiais de revestimentos e 


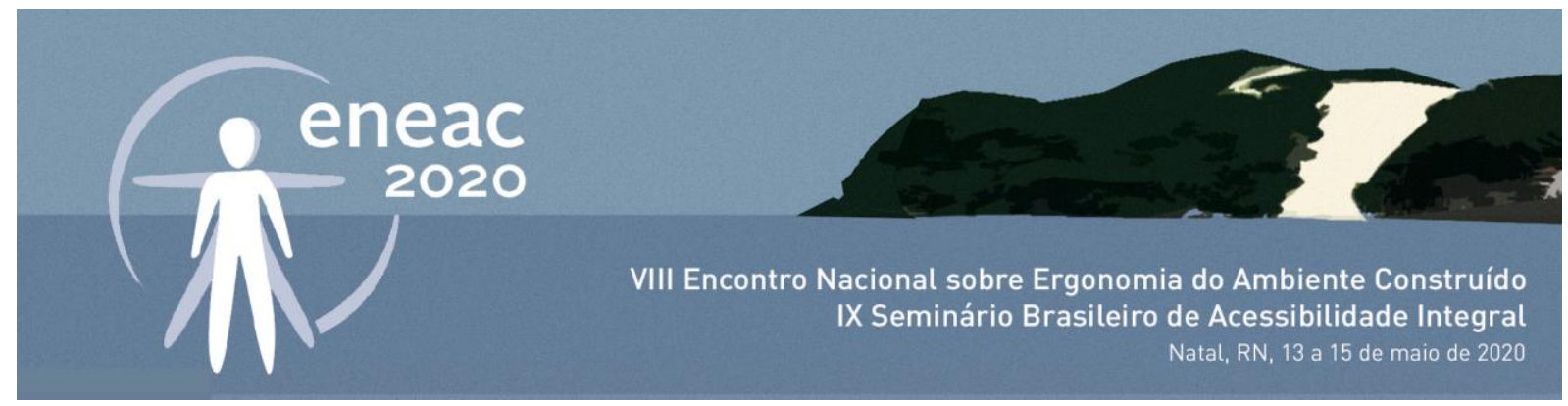

condições de acessibilidade, levantando-se as primeiras hipóteses sobre a questão das influências do espaço na execução das atividades do trabalho.

Figura 1: Planta baixa com layout, estudo de fluxo e espaço de movimentação da BJC

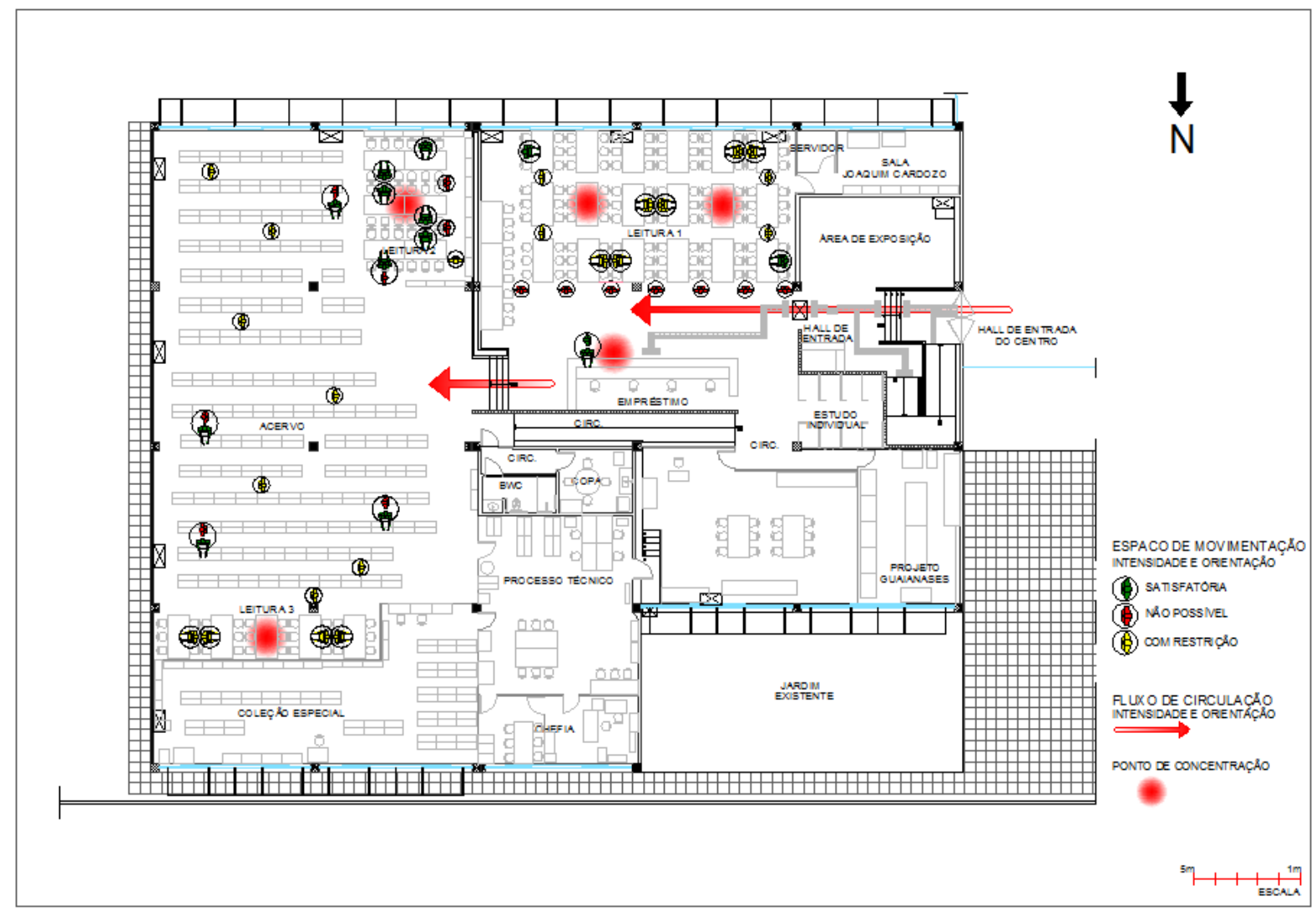

A partir do estudo do layout é identificado que o espaço é subdimensionado para as necessidades, notadamente na área das mesas de estudo, que não raras vezes, encontra-se com $100 \%$ de ocupação. A avaliação mais detalhada encontra-se no item 3.1.3.

\subsubsection{Acessibilidade}

A biblioteca possui uma rampa de acesso ao seu interior, que respeita as normas da NBR 9050, além de piso tátil da porta de entrada até o balcão de empréstimo, passando pela rampa e pela escada de acesso. A rampa de acesso ao acervo encontra-se completamente escondida por trás do balcão de empréstimo, sem sinalização para identificá-la, além de não possuir corrimão e material antiderrapante. A escada de acesso ao acervo, que se encontra em um pavimento semi-elevado, também não possui corrimão. Alguns espaços de circulação são apertados, restringindo o acesso. 0 balcão de empréstimo não conta com área de aproximação nem altura adequada para atendimento de cadeirantes. $\mathrm{Na}$ área do acervo as estantes não são adaptadas para acesso em altura menor e o corredor entre estantes é estreito. 


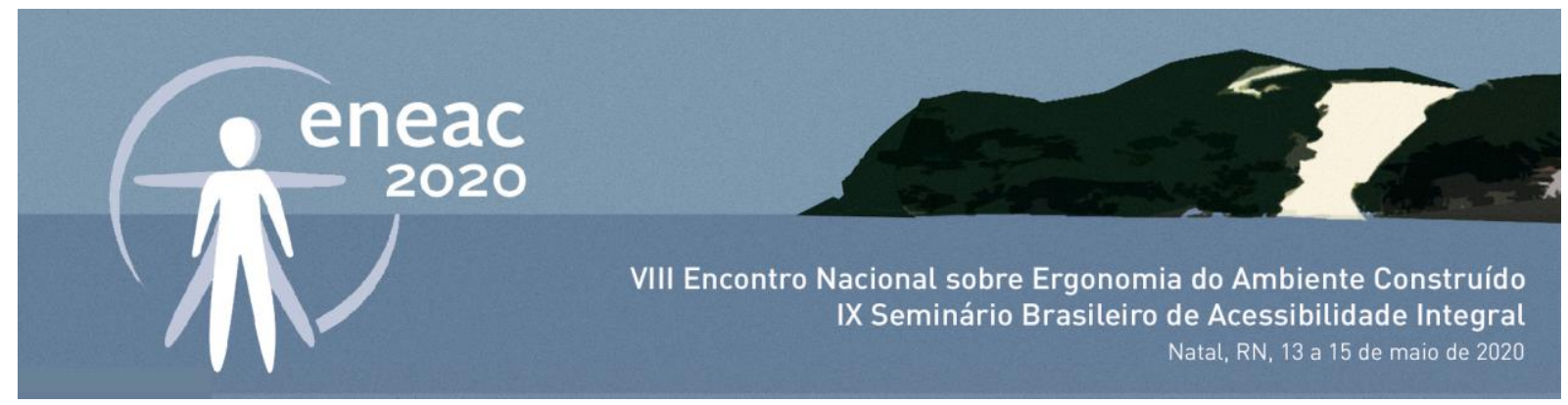

\subsubsection{Segurança}

Contando com uma única porta de acesso para entrada e saída, vê-se configurada o alto risco às pessoas usuárias do espaço caso ocorra um incêndio. Não há plano de rota de fuga nem brigada de incêndio no edifício.

\subsubsection{Análise das condições de iluminação}

Na pesquisa de campo foram observados alguns fatores que interferem na iluminação da biblioteca. A superfície envidraçada da área de leitura apresenta problemas de insolação no período da manhã, apesar da existência de brises em concreto armado no lado externo do edifício (figura 2). Na área de acervo, as janelas são pequenas e não oferecem iluminação natural adequada. A iluminação artificial é formada por luminárias com lâmpadas fluorescentes de $40 \mathrm{w}$ e permanecem acesas durante todo o dia, sendo verificado que não há balanceamento da iluminação, mesmo a despeito da área próxima às janelas registrar excesso de iluminação.

Figura 2 - Janelas com brises ao fundo da área de leitura.

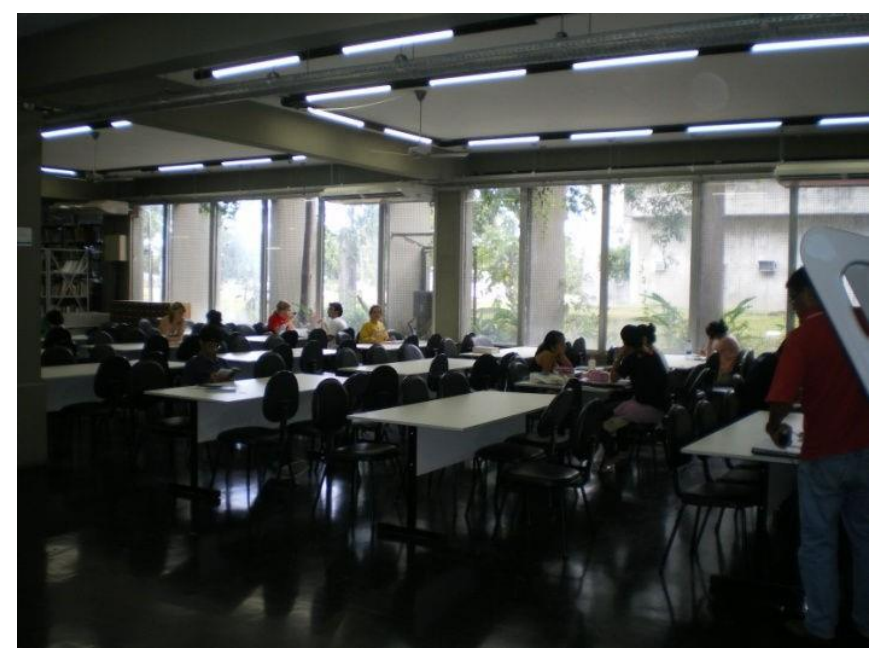

As medições de luminosidade foram realizadas com o luxímetro digital MINIPA, em 11 diferentes pontos em três momentos do dia, pela manhã (9:00), à tarde (15:00) e à noite (19:00). Os resultados foram comparados aos índices definidos na norma NHO 11, conforme estabelece a NR 17 (norma de ergonomia), que define iluminância de 300 lux para ambientes de estantes e fichários, e 500 lux para salas de estudos e leitura.

A partir dos resultados encontrados, observa-se que durante o dia as mesas de leitura localizadas nas proximidades das janelas recebem incidência direta da luz solar, com valores maiores que 1000 lux, muito acima do estipulado em norma, causando ofuscamentos. À noite, ao contrário, os referidos valores estão bem abaixo dos índices indicados. As medições dos pontos que correspondem às estantes de livros registram valores abaixo de 50 lux, tanto durante o dia quanto à noite, demonstrando que todos estão bem diferentes do valor recomendado, indicando que a iluminação no local não está bem distribuída, trata-se de um ponto grave a ser revisto. Na área das baias para estudo individual índices registrados, entre 70 e 120 lux estão muito abaixo do indicado, verificando- 


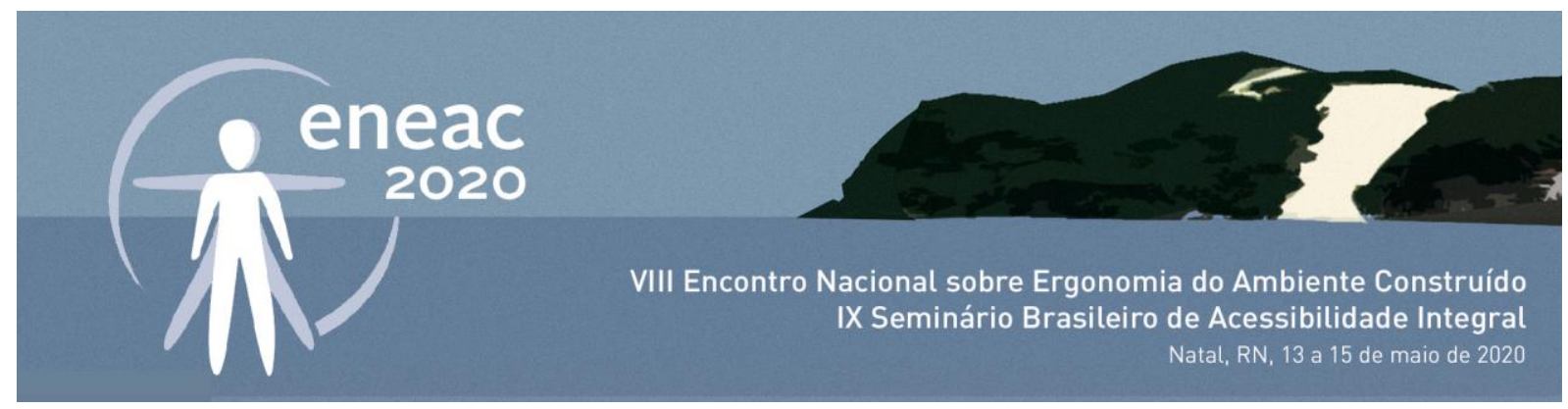

se assim uma necessidade imediata de intervenção. Situação similar foi registrada no balcão de atendimento.

Na perspectiva de identificar se os usuários percebem estas discrepâncias em relação aos índices de conforto, foi adotado um instrumento de avaliação da percepção dos usuários às condições lumínicas, acústicas e térmicas do ambiente da biblioteca. Um questionário baseado em Parsons (2005) apud Vasconcelos et al (2010), foi aplicado a 20 pessoas, sendo que dentre os entrevistados 15 eram usuários que tinham o hábito de frequentar a biblioteca regularmente e 05 eram bibliotecários do quadro de funcionários.

No questionário de iluminação foram realizadas 02 indagações. A primeira, "Indique na escala abaixo a sua opinião quanto à iluminação da biblioteca", possui uma variação na escala perceptiva de muito claro / pouco claro / confortável / pouco escuro / muito escuro.

Figura 3 - Gráfico da opinião dos funcionários da Biblioteca do CAC sobre a iluminação.

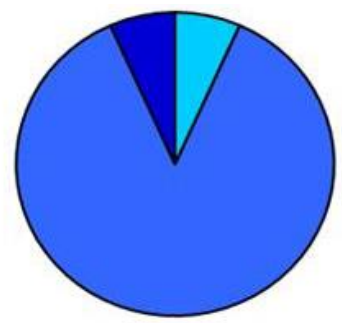

Figura 4 - Gráfico da opinião dos usuários da Biblioteca do CAC sobre a iluminação.

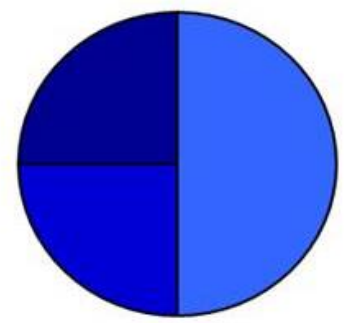

口MUITO CLARO

IPOUCO CLARO

口CONFORTÁVEL

- POUCOESCURO

- MUITO ESCURO

Como segunda pergunta no questionário de conforto ambiental lumínico inquiriu-se aos usuários e funcionários se eles percebiam algum tipo de incômodo proveniente do ambiente em que ele se encontravam. Enquanto $80 \%$ dos funcionários afirmavam que sim, 86,6 \% dos demais usuários disseram que não.

\subsubsection{Análise das condições de conforto acústico}

As condições de conforto acústico foram analisadas a partir das medições do ruído interno, com uma medição pela manhã (9:00) e outra à tarde (15:00), sendo descartada a medição à noite pelo grande decréscimo de usuários neste período. A fim de averiguar se os resultados estariam adequados, eles foram comparados com os índices considerados aceitáveis pela NBR 10.152 (ABNT, 2000), que estabelece que o índice aceitável para bibliotecas seria entre 35 e $45 \mathrm{~dB}(\mathrm{~A})$, tendo o nível de ruído sido medido com um decibelímetro ( ou sonômetro) digital da marca MINIPA. Em nenhum dos pontos aferidos o ambiente atende à norma, sendo encontrados índices que variam de 51 a $71 \mathrm{~dB}$.

Referente à pergunta de conforto ambiental acústico para o usuário, solicitou-se: "Indique na escala abaixo como você avalia o ruído no ambiente", em uma escala de muito barulho / pouco barulho / nem barulho nem silêncio / muito barulho. Sendo registradas as respostas constantes do quadro 1.

Dentre os funcionários $40 \%$ responderam pouco barulho e $60 \%$ nem barulho nem silêncio. Para os demais usuários $66,7 \%$ consideram pouco barulho, $20 \%$ nem barulho nem silêncio e apenas $13,3 \%$ responderam que há muito barulho. Embora se registre índices inadequados de ruído, as pessoas que utilizam o ambiente não se apercebem deste barulho excessivo.

No Brasil, trabalhos têm sido desenvolvidos no sentido de investigar este descompasso entre a 


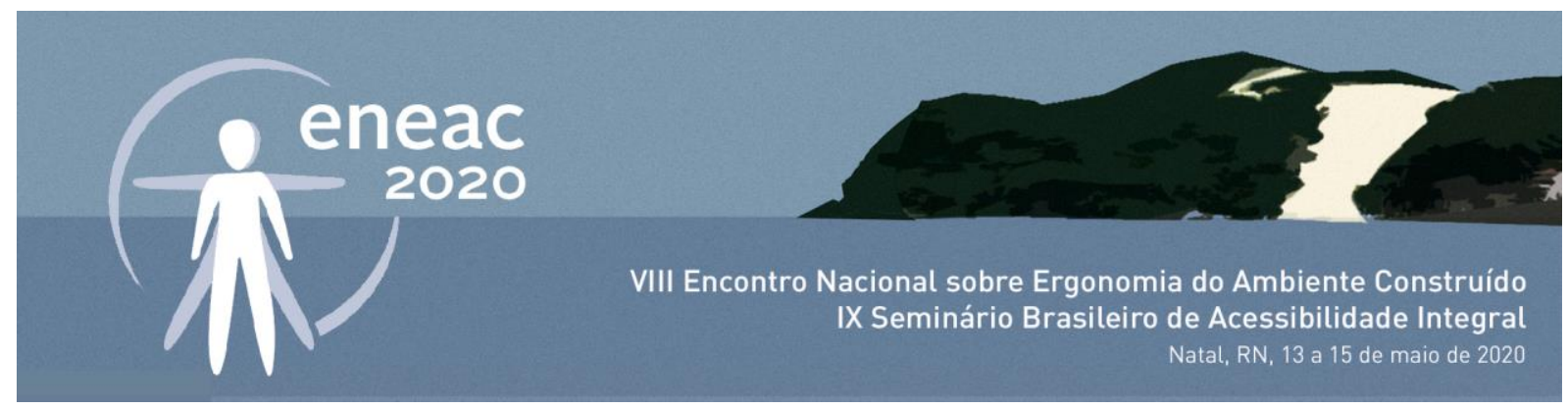

percepção das pessoas em relação ao conforto ambiental e as normas que regem tais variáveis.

\subsubsection{Análise das condições de conforto térmico}

A biblioteca do CAC foi projetada para receber um sistema de climatização e por esta razão a maioria das janelas é vedada. Isto dificulta muito quando acontecem problemas com os condicionadores.

A NR17 (norma de ergonomia) considera que a temperatura compatível ao desenvolvimento do trabalho, deve estar entre $20^{\circ}$ e $23^{\circ}$. Entretanto, deve-se pontuar que estando o ambiente avaliado na região nordeste as pessoas estão aclimatadas em outros níveis. Nesta direção considera-se o trabalho de Freitas (2008), quando afirma que:

\footnotetext{
"Um indivíduo em um clima temperado ou frio pode sentir-se confortável entre 14 e $18^{\circ} \mathrm{C}$. Enquanto isso, um habitante de um clima quente e úmido, como em Recife - PE, só vai sentir a mesma sensação de bem-estar em temperaturas próximas a $25^{\circ} \mathrm{C}$, para desenvolver suas atividades sem maiores esforços de adequação ambiental" (FREITAS, 2008, p.47).
}

Nessa direção e registrando temperaturas que variam de $22,9^{\circ} \mathrm{C}$ a $25^{\circ} \mathrm{C}$, pode se considerar que há adequação em relação ao conforto térmico na biblioteca.

Quanto à opinião dos funcionários e usuários da Biblioteca do CAC sobre sua sensação térmica, a partir das opções muito calor / calor / levemente calor / neutro / levemente frio / frio / muito frio, teve-se as respostas: 1) Funcionários com $20 \%$ com levemente calor, $40 \%$ neutro e $40 \%$ levemente frio; 2) Usuários com 6,7\% com calor, 53,3 neutro, 26,7 levemente frio e 13,3 com frio.

\subsubsection{Avaliação do Ambiente em Uso}

Finalmente, esta terceira etapa cuida da observação do ambiente em uso, visando identificar sua usabilidade, ou seja, o quanto facilitador ou dificultador ele representa ao desenvolvimento das atividades que abriga. Realiza-se uma análise efetiva do funcionamento do ambiente, com foco no desempenho do espaço construído, identificando inclusive, as interferências dos condicionantes espaciais na produtividade, se pertinente ao tipo de avaliação. Essa etapa consiste basicamente em observações na execução das tarefas e atividades. Aqui a antropometria apresenta grande colaboração quando o foco repousa no posto de trabalho e na avaliação de acessibilidade.

Neste trabalho, a planta encontrada na figura 1, contém a avaliação de circulação e mobilidade a partir da inserção de modelos antropométricos, que se apresentam na cor verde quando a circulação está livre e favorável, na cor amarela quando a passagem se dá com certa dificuldade e na cor vermelha quando não é possível a movimentação.

Em todo o ambiente de leitura principal (Leitura 1), que acolhe o maior número de pessoas, não é possível uma pessoa passar entre as mesas quando há pessoas sentadas. Para passar e acessar as cadeiras mais adiante é necessário que as demais levantem sendo incomodadas. Os modelos antropométricos aparecem em vermelho nesta direção, e, na direção contrária em amarelo. Não são registrados nenhum deles em verde.

No espaço de Leitura 2, o mesmo problema é identificado. Na área do acervo, os corredores estreitos entre as estantes não permite a passagem de uma pessoa, enquanto outra está consultando ou procurando livros.

Nas últimas décadas houve um incremento na quantidade de cursos ofertados, não havendo expansão física adequada para acomodar as centenas de novos alunos que foram agregados a partir 


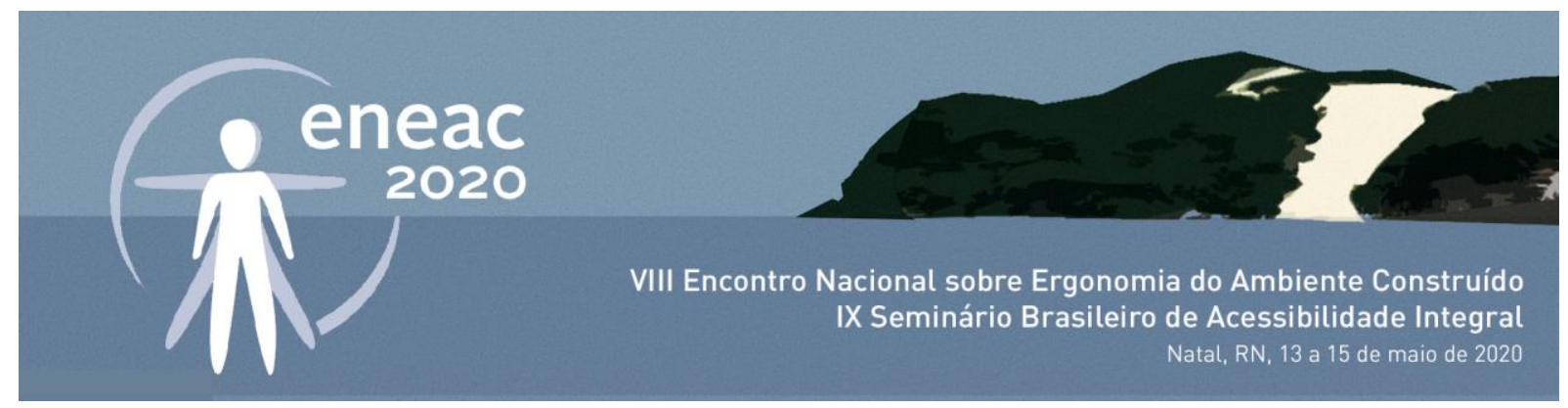

desse crescimento, nem na biblioteca, nem no edifício.

\subsubsection{Análise da Percepção Ambiental do usuário}

Diversas são as possibilidades neste campo de ferramentas de análise, dentre estas, na presente pesquisa foi utilizada a Constelação de Atributos. Idealizada por Moles (1968) e posteriormente trabalhada por diversos pesquisadores no Instituto de Psicologia Social de Estraburgo, entre eles Ekambi-Schimidt (1974), a ferramenta Constelação de Atributos tem por objetivo auxiliar os profissionais ligados à área de projeto, a fim de torná-los conhecedores da consciência psicológica do usuário frente ao espaço.

O instrumento da Constelação de Atributos foi aplicado com vinte usuários, com o objetivo de que os mesmos registrassem suas imagens e expectativas sobre um ambiente imaginário de uma biblioteca, como também do espaço real, seguindo os seguintes procedimentos: para a construção da Constelação de Atributos Imaginária, que remete à idealização do espaço fez-se a seguinte pergunta: "Quando você pensa em uma biblioteca, de uma maneira geral, que ideias ou imagens lhe vêm à mente", possibilitando a avaliação da imagem simbólica do indivíduo frente ao ambiente; para a construção da Constelação de Atributos Real (Figura 2), que permite a visualização concreta do ambiente, questionou-se aos mesmos entrevistados: "Quando você pensa nessa biblioteca que você frequenta, que ideias ou imagens lhe vêm à mente?" Isto permite a dissociação da ideia de afetividade que o usuário possa ter frente ao espaço que ele ocupa, permitindo uma análise mais metódica do objeto em estudo.

Figura 5 - Constelação de Atributos - ambiente imaginário

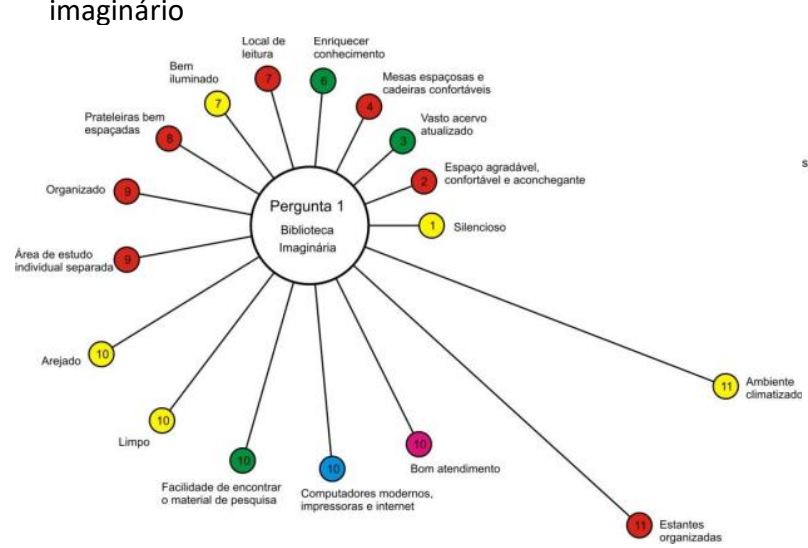

Figura 6 - Constelação de Atributos - ambiente real

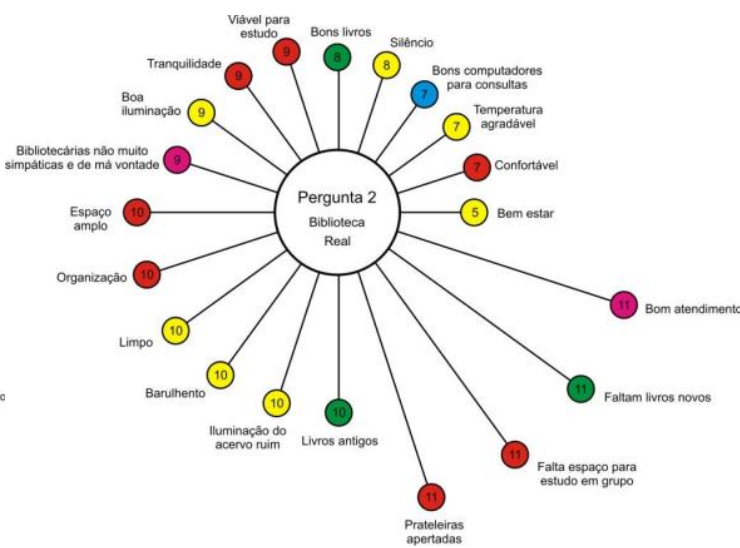

$\mathrm{Na}$ imagem simbólica da biblioteca, as pessoas idealizaram um ambiente organizado, silencioso e com um acervo satisfatório (figura 4). Já atributos mais citados para o ambiente real (figura 5), demonstraram a satisfação dos usuários quanto ao espaço da biblioteca, associando-a a bem estar, conforto, boa temperatura e bons computadores.

A próxima etapa da MEAC prevê a elaboração do diagnóstico, no entanto, neste trabalho está apresentado juntamente com o da biblioteca do DAUD-UFC, numa análise comparativa.

\subsection{Biblioteca do DAUD - UFC}

Inicia-se este tópico esclarecendo que as conceituações e detalhes da metodologia serão omitidos, uma vez que já se encontram explicitadas na análise apresentada no tópico anterior. 


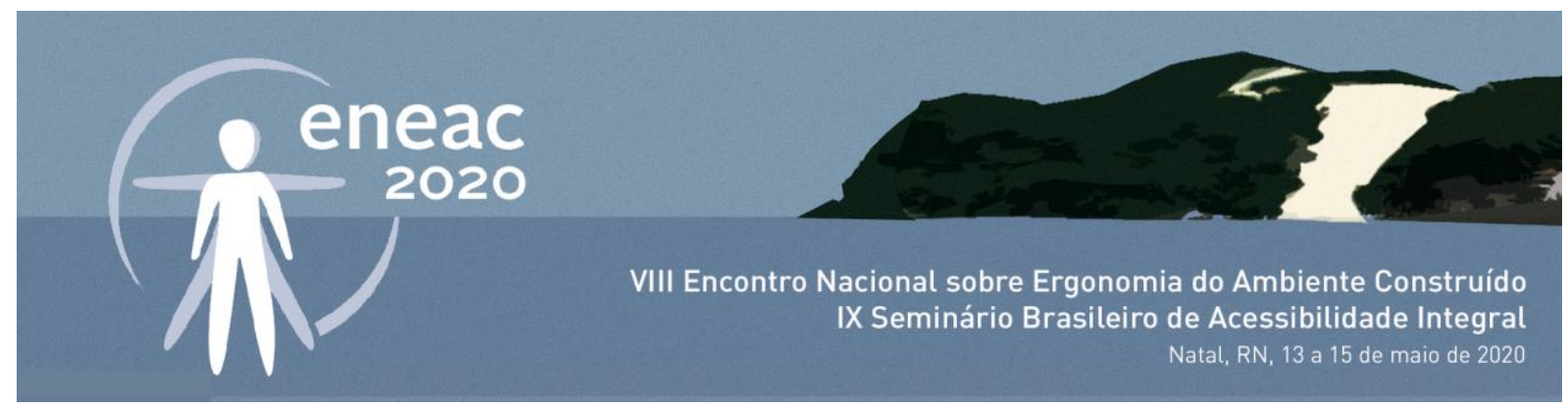

\subsubsection{Análise Global do Ambiente}

A biblioteca em estudo se localiza no Departamento de Arquitetura, Urbanismo e Design da Universidade Federal do Ceará. Conta com uma área de aproximadamente $360 \mathrm{~m}^{2}$, que consiste em recepção, espaço de estudo individual (mesas), acervo principal de livros, acervo de periódicos, sala de acervo de projeto e restauração de materiais, sala da chefia, sala dos funcionários, um pequeno depósito, um banheiro feminino e uma copa.

Está localizada em frente ao pátio principal e anfiteatro do departamento, que recebe com bastante frequência os eventos promovidos por alunos ou profissionais dos cursos, além de ser local de encontro e socialização entre os estudantes, ou seja, um espaço de grande produção de ruído. A fachada é voltada para o lado oeste, pintada na cor branca e com esquadrias em madeira e vidro, não sendo possível impedir a entrada de iluminação externa. A proteção solar das esquadrias é feita através da coberta da edificação que se estende gerando uma circulação coberta em toda a fachada. A presença de árvores no pátio também contribui para esta proteção das esquadrias.

Este espaço não foi originalmente planejado para abrigar a biblioteca, havia um salão muito grande onde os alunos estudavam e viravam a noite fazendo os trabalhos, principalmente os de Projeto Arquitetônico e de Projeto Urbanístico.

Figura 7 - Recepção da biblioteca

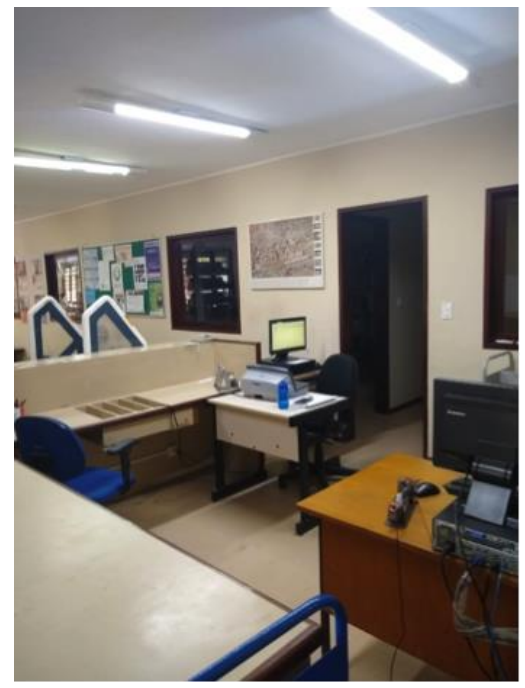

Figura 8 - Recepção da biblioteca

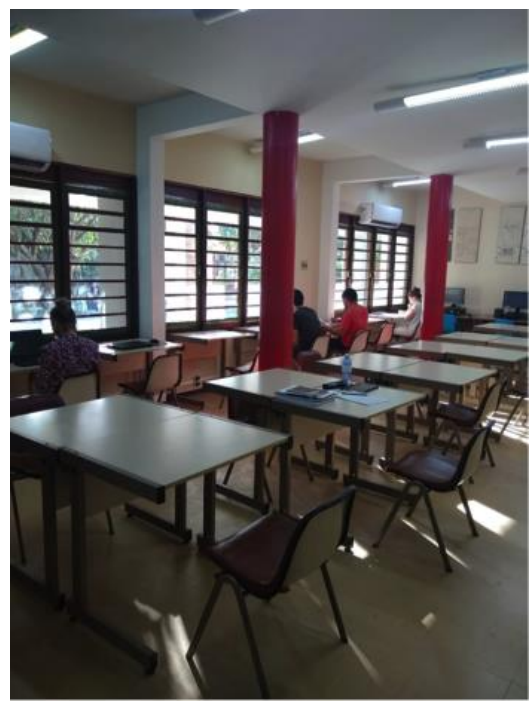

Os ambientes escolhidas para a análise da MEAC foram: recepção e a sala de trabalho dos funcionários, o acervo e a sala de mesas. A escolha da recepção se justifica por ser o primeiro espaço de permanência da biblioteca, além de ser local de primeiro contato entre os usuários e o funcionário da biblioteca. É na recepção onde se faz a locação e devolução dos livros. Logo na chegada a biblioteca os alunos são convidados a deixar bolsas, pastas ou outros pertences por questões de segurança, evitando que algum livro seja retirado do acervo sem o prévio registro.

\subsubsection{Identificação da Configuração Ambiental}

A planta apresentada contempla o layout da biblioteca, mas também elementos que serão tratados no item da Avaliação do Ambiente em Uso, como a análise com modelos antropométricos e linhas de 


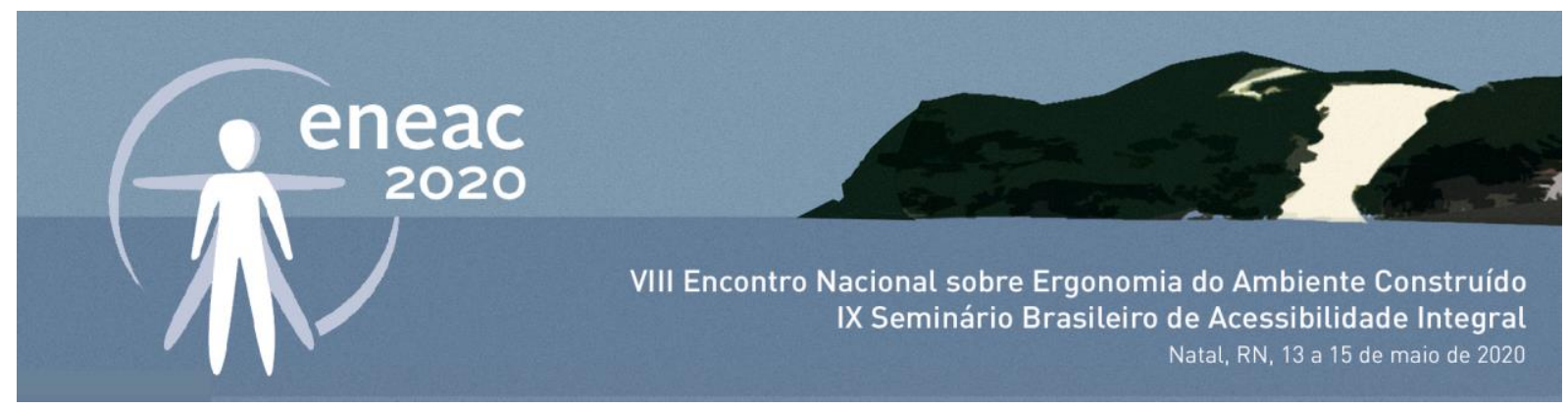

fluxo.

Figura 9: Planta baixa com layout, estudo de fluxo e espaço de movimentação da biblioteca do DAUD

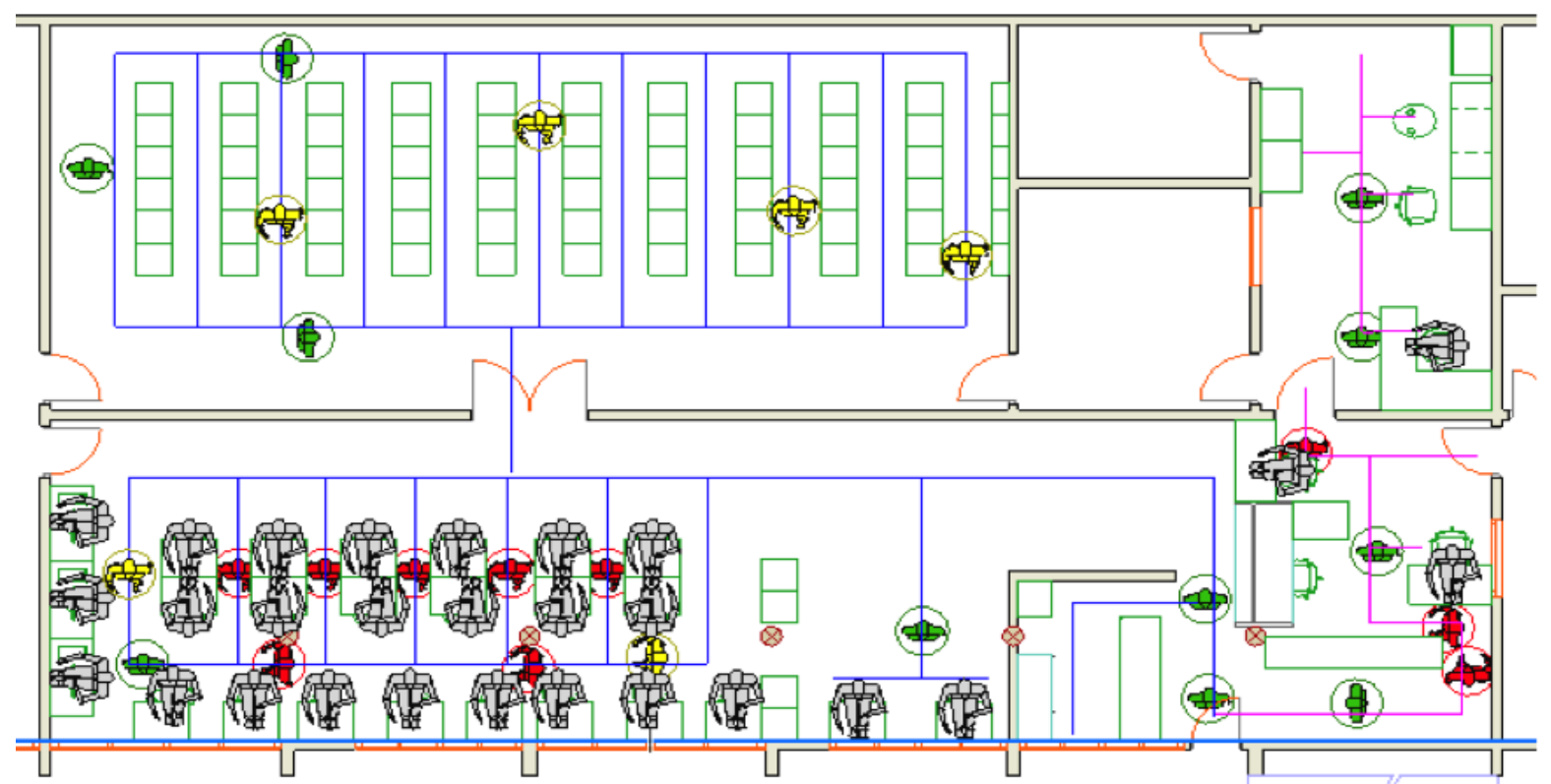

A observação do layout denota a carência de espaço para melhor desenvolvimento das atividades, notadamente no espaço de maior permanência dos usuários. A recepção também se mostra instalada em ambiente menor que o necessário para o desenvolvimento das atividades.

\subsubsection{Acessibilidade}

O acesso à biblioteca pode ser feito através da rampa, que não atende às exigências de acessibilidade, ou diretamente no patamar da rampa onde foi retirado parte do corrimão, como um tipo de degrau de acesso mais rápido à porta. A rampa não se inicia no mesmo nível do pátio, mas sim da calçada que vem acompanhando a edificação desde o hall de entrada do departamento até o acesso da cantina. Não há rampa que faça o acesso da calçada ao nível do piso do pátio em frente à biblioteca, assim, para que um cadeirante acesse a biblioteca é necessário que este se dirija primeiramente a rampa da cantina ou do hall.

$\mathrm{Na}$ área das mesas de estudo há poucos pontos onde seria possível acomodar uma cadeira de rodas, no entanto, as mesas não são apropriadas para facilitar este uso. No espaço não há qualquer sinalização em Braille nem piso podotátil, no sentido de permitir o acesso de pessoas cegas com autonomia.

\subsubsection{Segurança}

Contando com uma única porta de acesso para entrada e saída, vê-se configurada o alto risco às pessoas usuárias do espaço caso ocorra um incêndio. Não há plano de rota de fuga nem brigada de incêndio no edifício. 


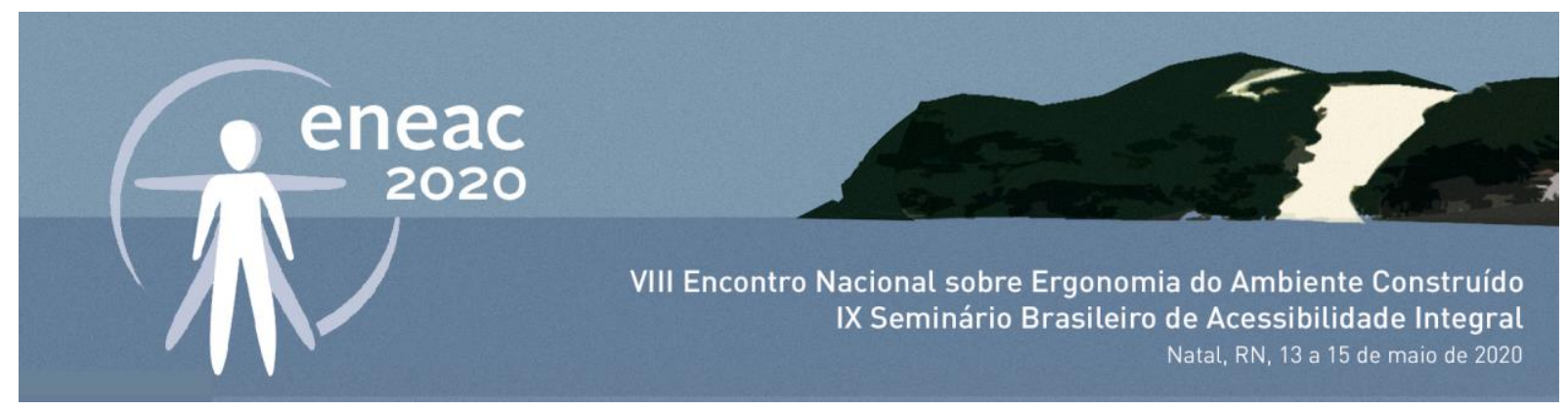

\subsubsection{Análise das condições de iluminação}

As medições foram realizadas foram realizadas no período da manhã às 10:30, à tarde as 15:00 e à noite às $18 \mathrm{~h}$, sendo estes resultados comparados com os níveis mínimos de iluminância estabelecidos na NHO 11 que estabelece 200 lux para área de estantes, 500 lux para trabalho de bibliotecárias e de 500 lux para a área de leitura. Optou-se por fazer as medições em nove pontos diferentes da área de leitura - considerando mesas próximas à janela, próximas a fonte de luz artificial localizadas no teto e outras que não estão próximas a essas fontes de luz, além de fazer as medições com e sem usuário na bancada.

No ambiente das mesas nenhum dos pontos recebe a quantidade mínima de iluminação em nenhum período do dia, exceto em um só ponto que no período da tarde recebe iluminação de 519 lux, porém este valor é reduzido para menos da metade, 219 lux, quando há usuário na bancada, ou seja, nenhuma das mesas da área de leitura da biblioteca possui iluminação adequada para a atividade de leitura; Na área do acervo todos os valores encontrados foram superiores ao valor mínimo indicado de 200 lux. Porém no período noturno, foi realizada uma medição bem próxima aos livros de prateleiras mais inferiores e o valor caiu para 028 lux. Em nenhuma das medições o valor mínimo de 500 lux foi atingido para as bancadas de trabalho das bibliotecárias.

O questionário sobre iluminância era composto de duas perguntas, igualmente ao realizado na primeira biblioteca. Apesar de ter sido constatado com a medição que nenhum ponto da área das mesas possui iluminação adequada para a atividade de leitura, todas $(100 \%)$ as respostas recebidas dos usuários foram de que a iluminação é confortável. Contudo, alguns incômodos como o ofuscamento causado pelos raios solares atingindo as mesas próximas as janelas por volta das 16:00 e a baixa iluminação noturna quando há apenas o uso de luz artificial foram relatados no segundo tópico. Na área do acervo as respostas apresentaram tímida variação, "pouco claro" (3) e "pouco escuro" (4), porém a maioria dos entrevistados (8) também considera "confortável" a iluminação da área dos livros. Os usuários identificaram como possível fonte de desconforto a pouca distância entre as estantes, gerando sombreamento no corredor e deixando as prateleiras mais baixas bastante escuras.

\subsubsection{Análise das condições de conforto acústico}

As medições do ruído foram realizadas em 6 pontos distintos, um na sala de trabalho, um na recepção, dois no acervo e dois na área de mesas, para que se pudesse fazer comparação do ruído na área central do ambiente e na área próxima a localização das máquinas de ar-condicionado. Com isso, pode-se constatar que de fato há uma variação - na área de mesas de $3 \mathrm{~dB}$ e no acervo de $10 \mathrm{~dB}$, que pode ser vista como significativa se considerada a pouca distância entre esses pontos. A sala de trabalho dos funcionários apresentou o menor nível de ruído em $48 \mathrm{Db}$. Na sala de estudo e acervo teve uma variação entre 57 e 61 Db, todos acima do recomendado, considerando a NBR 10.152/2017 que dispõe sobre o nível de ruído para conforto acústico, o valor máximo de $45 \mathrm{~dB}$ para área de biblioteca.

Estes níveis elevados não são percebidos pelos usuários dos espaços, uma vez que, quando indagados sobre sua percepção acerca do ruído, responderam em sua maioria que havia pouco barulho. $\mathrm{O}$ questionário sobre o conforto acústico também era composto de duas perguntas. $\mathrm{A}$ primeira solicitava classificar o ruído do ambiente com "muito barulho - pouco barulho - nem barulho nem silêncio - muito silêncio", sendo obtidas respostas entre sem barulho e pouco barulho, não se 


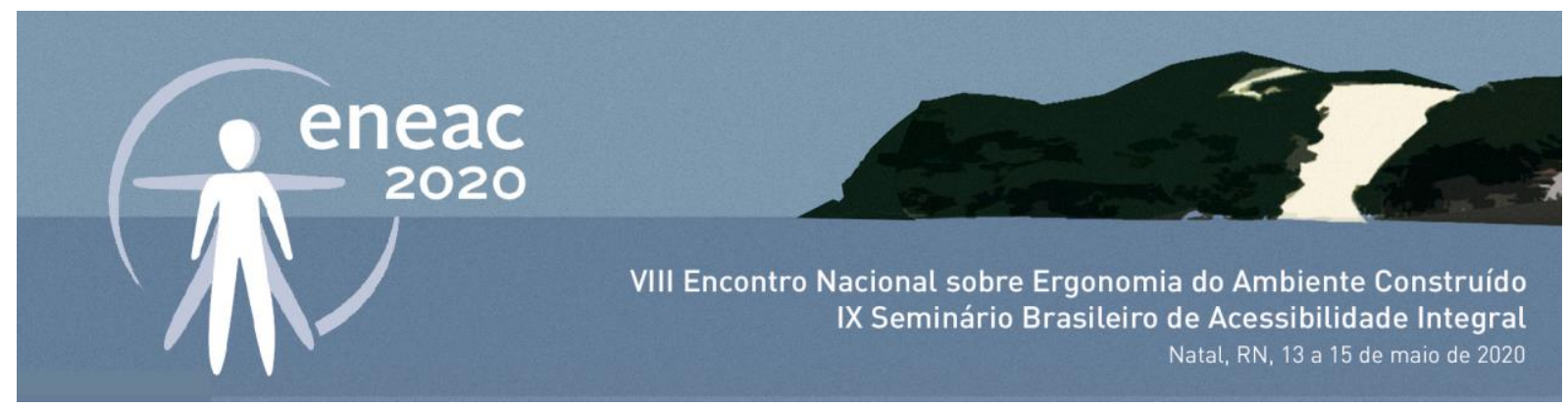

registrando nenhum respondente que considerasse o local muito ruidoso.

\subsubsection{Análise das condições de conforto térmico}

As medições de temperatura foram realizadas através de um termômetro de globo em cada um dos espaços em estudo, nos períodos da manhã (9:00), tarde (13:00) e noite (18:00) em um dia ensolarado de 31 C (Clima Tempo. StormGeo Company). Vale ressaltar que em cada um dos espaços possui pelo menos 1 (um) aparelho de ar condicionado regulado na temperatura de $24 \circ \mathrm{C}$.

As temperaturas encontradas variaram de $23.8^{\circ} \mathrm{C}$ a $33.1^{\circ} \mathrm{C}$, estando em desacordo tanto com o que preconiza a NR17, quanto à indicação de Freitas (2008) de tê-las em torno de $25^{\circ} \mathrm{C}$.

Apesar de todos os valores de temperaturas obtidos estarem acima do indicado na norma, os usuários mostraram-se em sua maioria bastante satisfeitos com a sensação térmica do ambiente. 0 questionário sobre o conforto térmico era composto pelas seguintes perguntas: "qual a sua sensação térmica neste ambiente?" e "como preferia estar se sentindo agora?", ambas com indicação na escala proposta.

\subsubsection{Avaliação do Ambiente em Uso}

Analisando a planta (figura 8), nota-se 35 modelos antropométricos na área das mesas, dos quais 25 estão sentados, 2 estão verdes, indicando circulação adequada, 2 estão amarelos, indicando circulação que exige atenção e 7 estão vermelhos, indicando circulação impossibilitada. Desse modo, pode-se afirmar que a maioria das passagens do percurso realizado no ambiente é inadequada.

No acervo, há 3 bonecos verdes e 4 amarelos, totalizando 7. Neste ambiente a maioria das passagens exige atenção. Na recepção em conjunto com o guarda-volumes, há 2 sentados, 4 verdes, sendo 2 na entrada, passando próximo ao guarda-volumes e 2 no ambiente da recepção de fato, e 3 vermelhos. Esta contagem nos mostra algumas passagens estranguladas pelo mobiliário. Na sala de trabalho, nota-se 3 bonecos sentados e 2 verdes que circulam confortavelmente.

A configuração ambiental da biblioteca, tanto pelo aspecto dimensional, quanto pelo layout implantado, não colabora para o bom desenvolvimento das atividades ali realizadas.

\subsubsection{Análise da Percepção Ambiental do usuário}

Nesta fase onde é analisada a relação dos usuários com o ambiente várias metodologias podem ser utilizadas, a fim de buscar entender melhor como os indivíduos se sentem naquele espaço e qual sua relação com ele, visto que as pessoas devem ser o foco do projeto arquitetonico, notadamente quando nele se insere o foco da ergonomia. Foram utilizados dois métodos diferentes de análise da percepção do usuário, a Constelação de Atributos para os estudantes e o Poema dos Desejos para os funcionários.

Observando-se a Constelação gerada pelas respostas dos estudantes em relação ao ambiente real da biblioteca (figura 9), o principal atributo foi a falta de espaço para estudo em grupo, o tamanho reduzido do espaço da biblioteca, a falta de tomadas também foi um fator muito presente, o barulho e o ambiente pouco convidativo. 


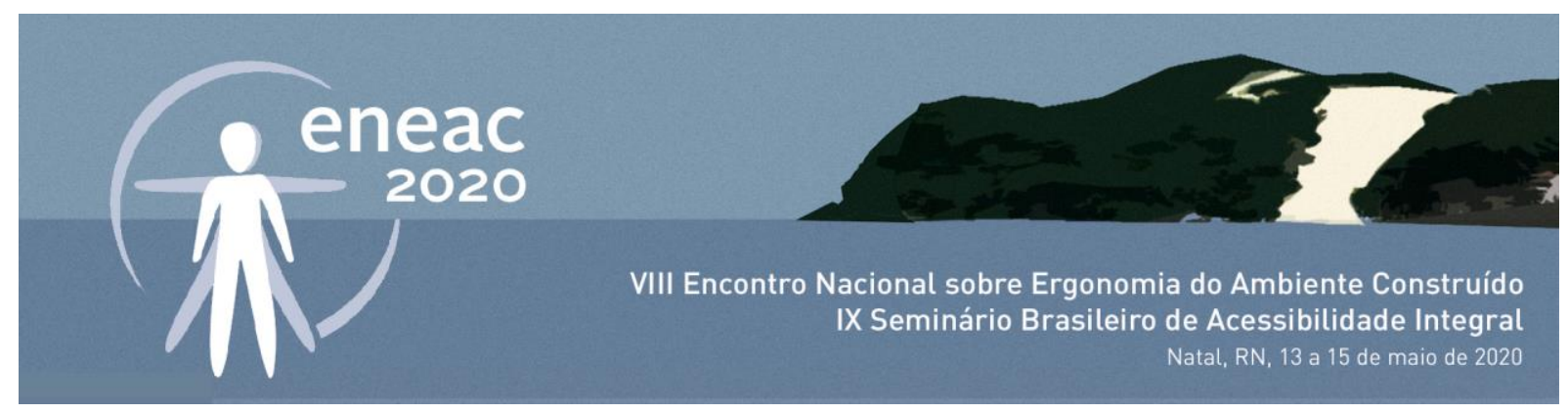

Figura 10 - Constelação de Atributos - ambiente real

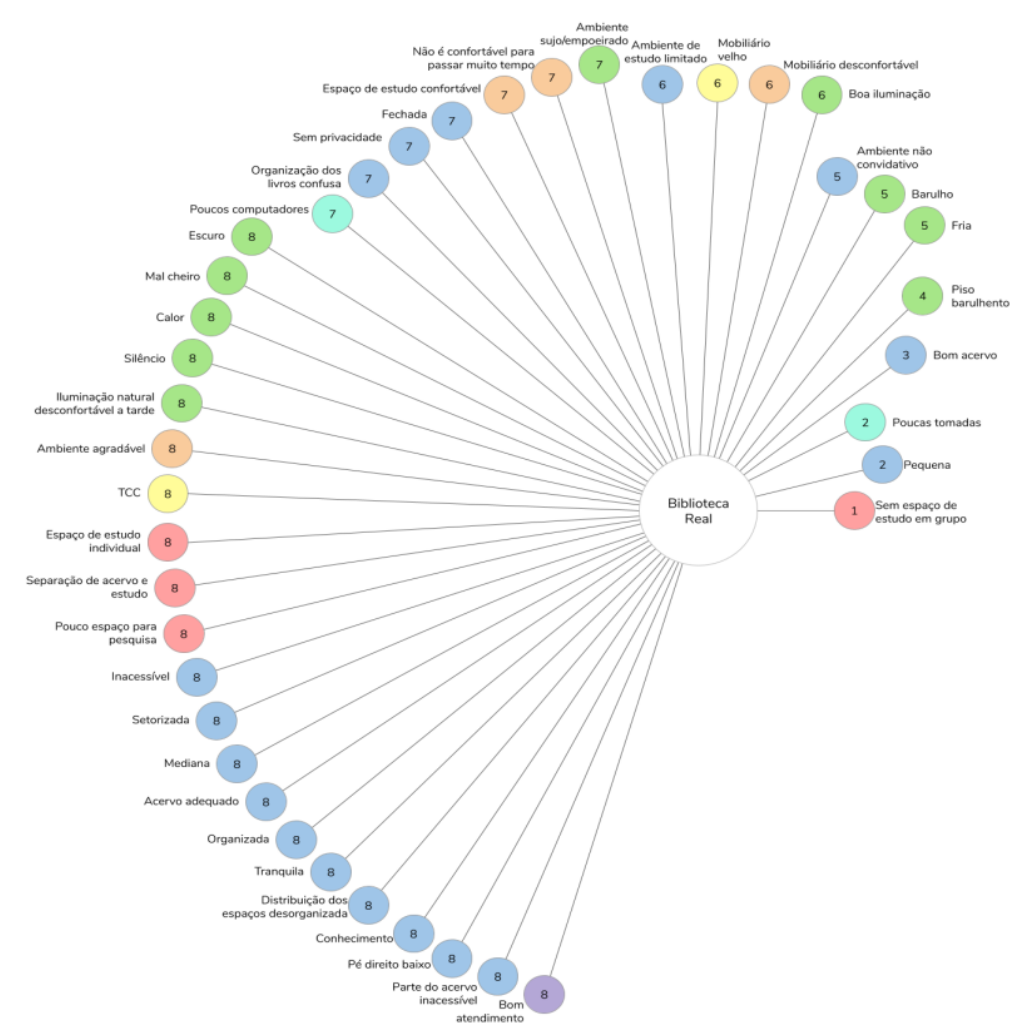

O Poema dos Desejos usados para os funcionários, devido à natureza das atividades e também por ser um número mais reduzido, consiste em um conjunto de sentenças, desenhos ou qualquer forma de expressão que expresse as necessidades, sentimentos e desejos referentes ao ambiente analisado. A equipe conversou com os funcionários e explicou como se dava o processo relativo a essa ferramenta, então foi entregue um papel com a indagação "Eu gostaria que a biblioteca do DAUD fosse..." e esperou-se para registrar suas respostas. Após a análise das respostas dos funcionários, pôde-se perceber uma necessidade principalmente de mobiliário adequado, tanto para os funcionários quanto para a área de estudo utilizada pelos estudantes, além de identificação de problemas nas instalações elétricas, também citaram que poderia haver câmeras internas para garantir a segurança do local.

\section{DIAGNÓSTICO E CONCLUSÕES}

Diante do importante papel das bibliotecas universitárias, vê-se em anos recentes, algumas ajustarem-se às novas demandas à exemplo do que é encontrado na Europa e países desenvolvidos. Pode ser citada como exemplo a Biblioteca Central da UFPE, que além do acervo e espaços de estudos com variadas configurações, disponibiliza ao público usuário auditórios, salas para pequenas reuniões, espaço para exposições, o Memorial Denis Bernardes com um riquíssimo acervo histórico, além de um importante serviço de tecnologia da informação e digitalização de acervos. Nesta universidade, além da Biblioteca Central, existem as setoriais nos prédios dos centros acadêmicos. 


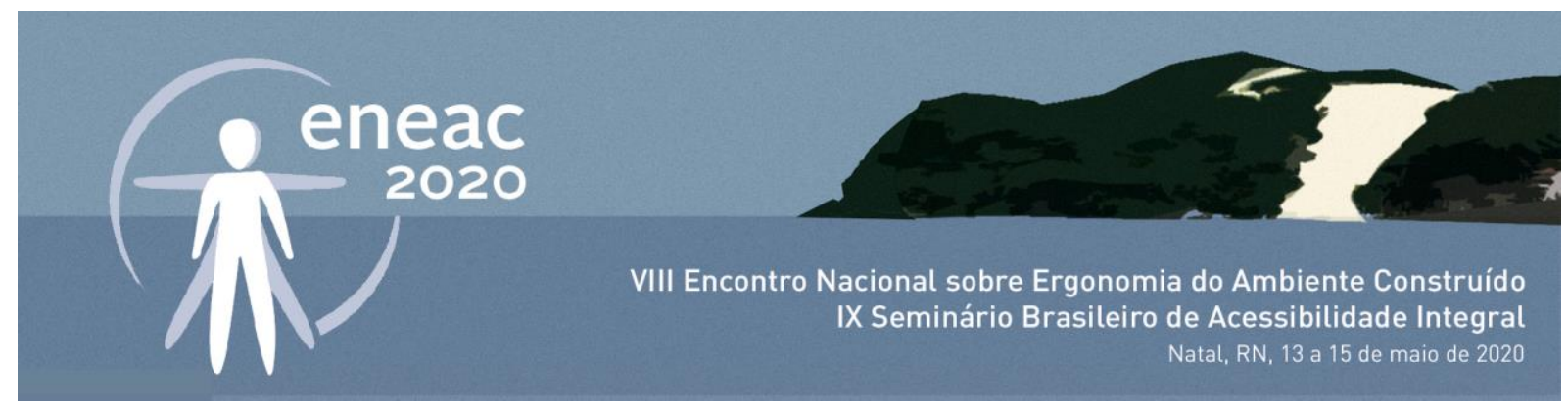

O estudo de casos tratado neste texto aborda situação peculiar de bibliotecas inseridas nos edifícios onde estão os cursos de arquitetura e urbanismo, onde se estuda e pesquisa a produção de espaços edificados e urbanos. Nestas se espera encontrar configurações ideais, com conforto e adequação, além de estética agradável.

Tendo como ponto de partida as perguntas colocadas no tópico 2, a avaliação foi realizada em duas bibliotecas de prédios onde estão os cursos de arquitetura de duas universidades públicas do nordeste, sendo encontradas diversas inconformidades, como exposto ao longo do texto.

Na biblioteca do CAC-UFPE os problemas são identificados no espaço insuficiente, layout inadequado, condições de conforto ambiental divergentes do que está prescrito nas normas, acessibilidade deficiente, segurança comprometida e mobilidade prejudicada. Além disso, carece de espaços adequados para estudo individual e de ambientes para estudos de equipes, de equipamentos especiais para leitura com conforto e de postos de trabalho melhor adaptados aos funcionários.

Para a biblioteca do DAUD-UFC foram identificadas dificuldades muito similares, sendo ainda agravadas pelo acesso complicado que dificulta sua utilização pelas pessoas com mobilidade reduzida.

Sob o foco dos usuários, nem sempre os problemas são percebidos como se verificou nas questões de iluminação, temperatura e ruído, no entanto, a Constelação de Atributos do ambiente imaginário, trás à tona imagens espontâneas e revelações subjetivas, onde via de regra, aparecem valores que o indivíduo gostaria de ter, mas que são frustrados no ambiente vivenciado. Assim, atributos como ter espaço de leitura, espaço agradável, confortável e aconchegante, mesas e cadeiras confortáveis, prateleiras (estantes) espaçosas, área de estudo individual separada, arejado, espaço amplo, são citados pelos usuários.

Para a biblioteca do DAUD os usuários a consideram: ambiente não convidativo, pequena, com barulho, sem espaço de estudo em grupo, não é confortável para passar muito tempo, ambiente de estudo limitado, mobiliário desconfortável, entre outros.

Com base nos resultados, as respostas às perguntas de partida da pesquisa apresentam-se todas negativas, quando se identificou que as bibliotecas de faculdades de arquitetura NÃO são adequadas ao desenvolvimento das atividades nela abrigadas; elas NÃO atendem às expectativas dos usuários e NÃO estão em conformidade com as normas técnicas.

Certamente que não se pode generalizar os resultados encontrados em um estudo com apenas dois casos, no entanto, os itens de inconformidade identificados podem servir de base a um check list a ser aplicado em muitas outras bibliotecas de faculdades de arquitetura, representando uma importante contribuição aos estudos da ergonomia aplicada ao ambiente construído.

Trabalhos desta natureza apontam para a necessidade de inserir e/ou reforçar os estudos da ergonomia nos cursos de arquitetura. A abordagem sistêmica por ela conduzida contribui inequivocamente para a consecução de projetos melhor adequados aos seus usuários e às atividades que neles são realizadas. No entanto, estudo recente, identifica que não ultrapassa dos $20 \%$ as faculdades públicas de arquitetura brasileiras que tem a disciplina de ergonomia aplicada ao projeto como obrigatória. 


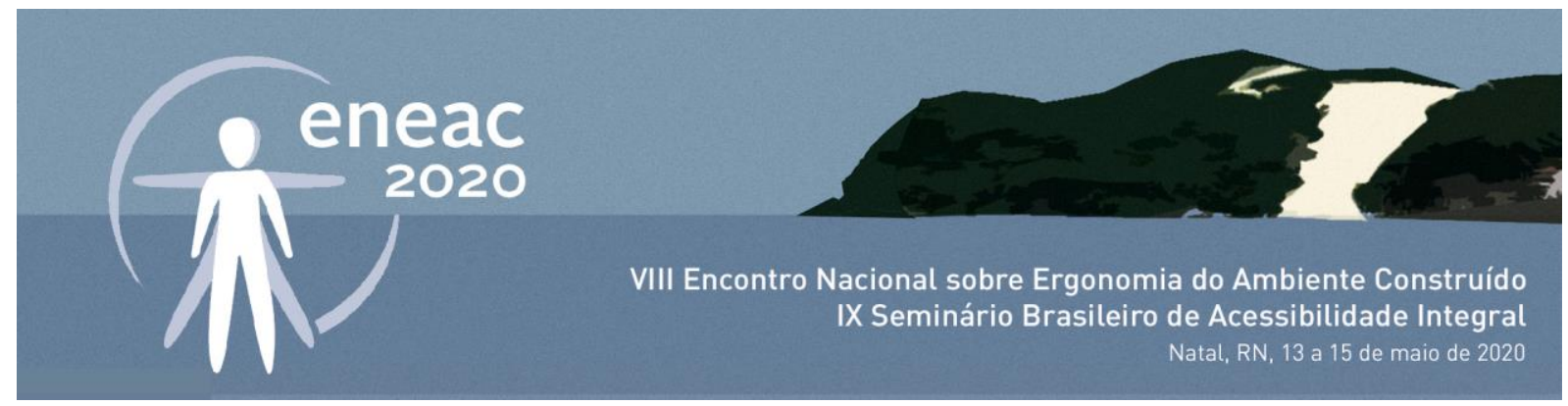

\section{AGRADECIMENTOS}

Ao programa PIBIC/UFPE/CNPQ que através de bolsas de Iniciação Científica viabilizou a realização da pesquisa em todas as bibliotecas do Campus Recife da UFPE no período de quatro anos entre o ano de 2009 a 2013. Os bolsistas do curso de Arquitetura e Urbanismo, Nicole Ferrer, Natália Tapety e Saulo Freitas. À FUNCAP e ao Programa PIBITI/UFC que através de Bolsas de Iniciação Científica e Iniciação Tecnológica viabilizaram esta pesquisa.

\section{REFERÊNCIAS}

BRASIL. Ministério do Trabalho e Emprego. NR 17 - Ergonomia. Brasília: 2007.

FERRER, N. CAC - Relatório final. Relatório da pesquisa desenvolvida no Programa PIBIC, Departamento de Expressão Gráfica, UFPE. Recife, PE, 2012.

FREITAS, R. Entre mitos e limites: as possibilidades do adensamento construtivo face à qualidade de vida no ambiente urbano. Recife: Editora Universitária da UFPE, 2008;

GIL, A. C. Como elaborar projetos de pesquisa. 4. ed. São Paulo: Atlas S.A., 2010.

GIL, A. C. Métodos e técnicas de pesquisa social. 6. ed. São Paulo: Atlas, 2008.

Grosso, A. C. M. Qualidade Visual Percebida em cenas do Edifício do Centro de Artes e Comunicação da Universidade Federal de Pernambuco. Dissertação. Mestrado Profissional em Ergonomia, Universidade Federal de Pernambuco, UFPE, 2018.

MONT'ALVÃO, C. A ergonomia do ambiente construído no Brasil. In: Mont'Alvão, C.; Villarouco, V. (Orgs.). Um novo olhar para o projeto: a ergonomia no ambiente construído. Teresópolis - RJ: 2AB, 2011, v. Único, p. 04-18.

PRADO, H. A organização e administração de bibliotecas. 2ª Ed. São Paulo: T.A Queiroz, 2003.

REIS, A. T. L.; LAY, M. C. D. Avaliação da qualidade de projetos. In: Ambiente Construído. Porto Alegre, v. 6, n. 3, p. 21-34, jul./set. 2006.

RUSSO, M. Financiamento para bibliotecas universitárias brasileiras. In: X Seminário Nacional de Bibliotecas Universitárias X SNBU. Anais. UFC, 1998.

SOARES, M. M.; VASCONCELOS, C. S. F.; VILLAROUCO, V. Avaliação ergonômica do ambiente construído: estudo de caso em uma biblioteca universitária. In: Ação ergonômica, [s.I.], v. 4, n. 1, p. 5-25, out. 2009a. Disponível em: http://www.abergo.org.br/revista/index.php/ae/article/view/69. Acesso em: 13-11-2019.

VASCONCELOS, C.; VILLAROUCO, V.; FERRER, N.; TAPETY, N. A visão do usuário sobre o conforto ambiental em uma biblioteca universitária. In: XIII Encontro Nacional de Tecnologia do Ambiente Construído, ENTAC. Anais.ANTAC, Canela, RS, 2010.

VASCONCELOS, C. S. F.; VILLAROUCO, V.; SOARES, M. Avaliação Ergonômica do Ambiente: Análise do conforto ambiental em uma sala de controle. In: X Encontro Nacional e VI Encontro Latino Americano de Conforto no Ambiente Construído, 2009, Natal. X ENCAC / VI ELACAC, 2009b.

VILLAROUCO. V. O ambiente este adequado? In: Encontro Nacional de Ergonomia do Ambiente Construído, I e Seminário Brasileiro de Acessibilidade Integral, II. 2007, Recife, Anais... Recife: ENEAC, 2007. 